\title{
U.S. Geological Survey Groundwater Modeling Software: Making Sense of a Complex Natural Resource
}

Computer models of groundwater systems simulate the flow of groundwater, including water levels, and the transport of chemical constituents and thermal energy. Groundwater models afford hydrologists a framework on which to organize their knowledge and understanding of groundwater systems, and they provide insights water-resources managers need to plan effectively for future water demands (fig. 1). Building on decades of experience, the U.S. Geological Survey (USGS) continues to lead in the development and application of computer software that allows groundwater models to address scientific and management questions of increasing complexity.

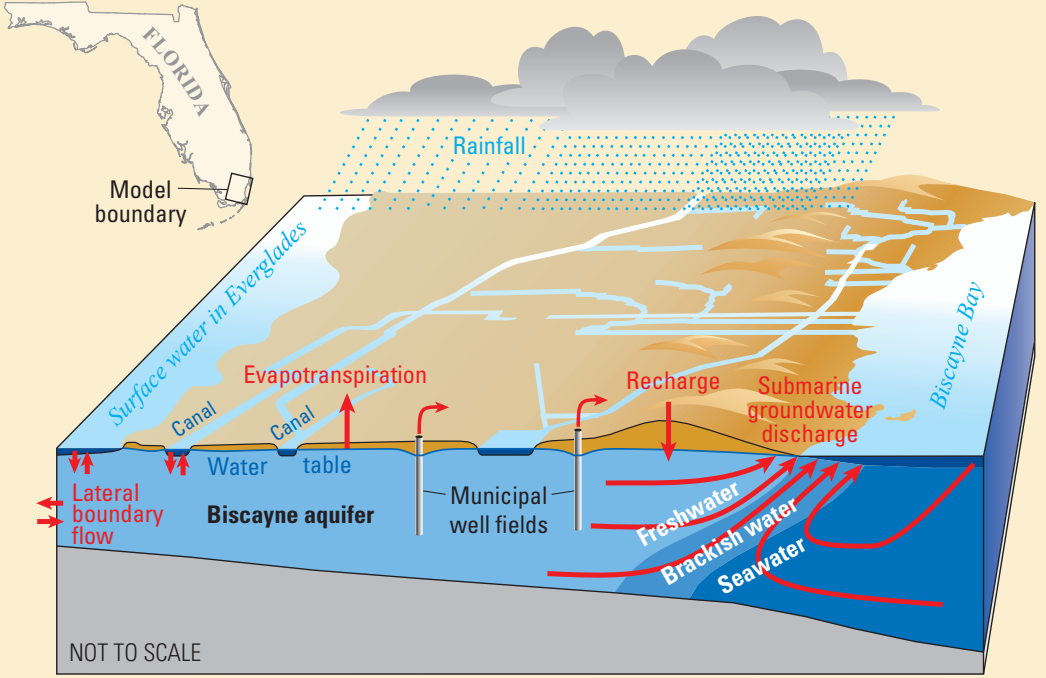

Figure 1. A conceptual model (above) of groundwater discharge to Biscayne Bay, Florida, forms the basis for a computer model (right) that simulates groundwater salinity in the coastal aquifer. Colors on map denote the transition from freshwater (tan) to seawater (red). (Figure modified from Langevin, 2001.)

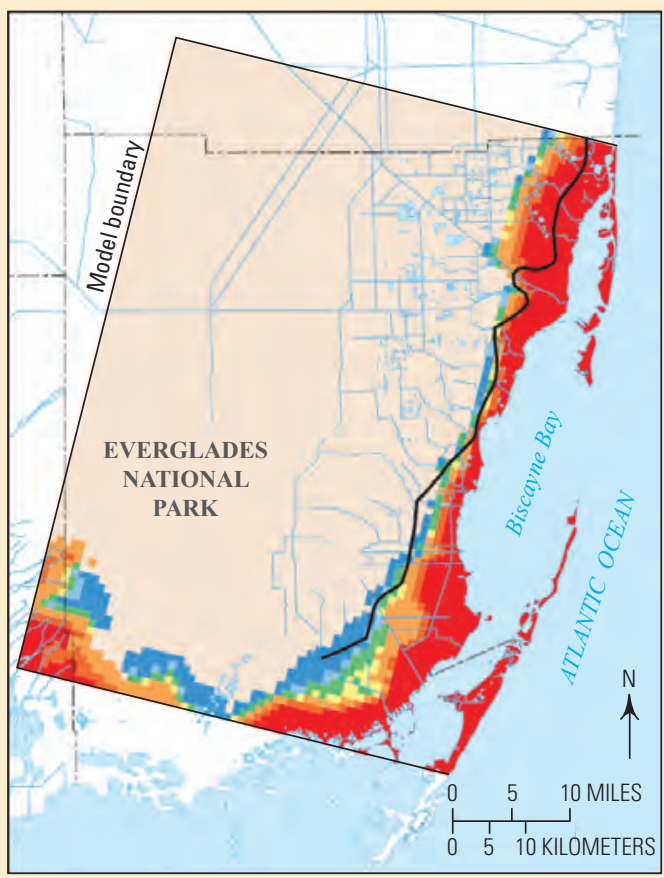

\section{Groundwater Flow and Transport Modeling: Moving From Paper to Silicon}

C.V. Theis (1935) of the USGS recognized that the flow of groundwater through porous materials is analogous to the flow of heat through conductive solids and deduced the equation that describes the hydraulic response of an idealized aquifer to a pumping well. Early groundwater models based on variations of Theis' formula represented highly simplified hydrogeologic conditions (Bredehoeft, 1976).

In the 1950s and 1960s, USGS hydrologists and others took further advantage of physical and mathematical analogies to create more realistic models of complex groundwater systems. These analog models cleverly exploited the properties of rubber sheets, resistance paper, electrolyte solutions, viscous fluids, and networks of resistors and capacitors to mimic the effects of hydrologic processes such as seawater intrusion, thermal convection, evapotranspiration, and flow through multilayered aquifers (Prickett, 1976).

As computers became increasingly powerful, affordable, and widely available in the 1960s and 1970s, many hydrologists turned to digital, or numerical, groundwater modeling. Most of the early numerical models were based on the finite-difference method, which is easy to understand and is founded on the same mathematical principles as the relatively expensive resistorcapacitor network models the method eventually supplanted (Prickett, 1976). The first groundwater modeling program developed at the USGS simulated flow in two dimensions (Pinder, 1969). Five years later, Trescott (1975) published a program that simulated three-dimensional flow. This program 
was widely used and underwent numerous modifications as USGS investigators adapted it to the needs of their groundwater studies.

The early 1970 s also saw the arrival of software for simulating movement of chemical constituents, or solute transport, in groundwater (Bredehoeft and Pinder, 1973; Rubin and James, 1973). A program developed by Konikow and Bredehoeft (1978) was the first publicly available USGS solute-transport simulator.

"Perhaps the most significant development in the field of water-quality hydrology during the 1970's was the increasing use of mathematical modeling techniques.

-J.D. Hem (1985)

By the early 1980s, numerical groundwater modeling was commonplace, and a number of programs were available to model typical conditions in a variety of aquifer systems. Differences in computer architecture and programming languages, inconsistent documentation, and variations in input-data requirements and output-data formats, however, complicated attempts to share programs and adapt them to new applications.

Researchers at the USGS undertook to resolve this difficulty, and in the winter of 1983 the USGS released to the public a modular three-dimensional finite-difference groundwater flow model, or MODFLOW (McDonald and Harbaugh, 1984). The program was written in the popular FORTRAN programming language to ensure its portability across a variety of computing platforms, and it was designed with a modular structure to facilitate the addition of new capabilities. In time, these attributes enabled MODFLOW to evolve into the most widely used groundwater modeling program in the world.

\section{Geochemical Modeling: Focusing a Powerful Lens on Water Quality}

As numerical modeling of groundwater flow gained momentum in the 1960s, so did the use of fundamental principles of aqueous geochemistry in the study of natural groundwater (Back and Cherry, 1976). Mathematical models of aqueous geochemistry, along with numerical solute-transport models, significantly expanded the array of tools available to hydrologists investigating water quality.

The chemical makeup of groundwater is the result of interactions between water and the various materials it encounters as it moves through the hydrologic cycle, such as gases, minerals, natural and manmade contaminants, and biological agents. The advent of computer programs that can solve the nonlinear equations of aqueous chemical equilibrium led to widespread use of a class of models called speciation models. Given concentrations of basic chemical components determined by laboratory analysis of a groundwater sample, along with temperature and other relevant environmental conditions, programs such as WATEQ (Truesdell and Jones, 1974) can estimate the equilibrium concentrations of dissolved chemical species and the tendency of solid minerals to precipitate or dissolve. Despite their limitations, speciation models provide important clues to the chemical processes that affect the composition of groundwater (Truesdell and Jones, 1974; Back and Cherry, 1976).

The next advance in geochemical modeling was to go beyond purely aqueous calculations and simulate the reaction of water with minerals and gases. Given an analyzed water composition, programs such as PHREEQE (Parkhurst and others, 1980) can estimate what the composition of water would be if it were to equilibrate with a specified set of minerals and gases. Geochemists use the results of such "forward" modeling, which proceeds from specified initial concentrations to computed final concentrations, to infer the origins, mobility, and toxicity of chemicals in groundwater under various conditions.

The chemistry of groundwater depends in large part on how it flows through the subsurface (fig. 2). Thus, geochemistry can provide valuable insight into the origins of groundwater and the paths along which it flows. The computer program NETPATH (Plummer and others, 1991) facilitates understanding of the relations between groundwater flow and chemistry by allowing "inverse" modeling of waters encountered along a hydrologic flow path. Given an initial water composition, or a set of waters that can be mixed together, and information regarding the minerals and gases that can enter or leave the water, NETPATH computes all possible mixing proportions and net geochemical mass-balance reactions that can account for an observed final water composition.

WATEQ, PHREEQE, NETPATH and their derivatives have been used widely both inside and outside of the USGS. These programs have been modified since their initial releases to include an ever-widening array of processes, including ion exchange, sorption, solid solutions, environmental isotopes, and reaction kinetics.

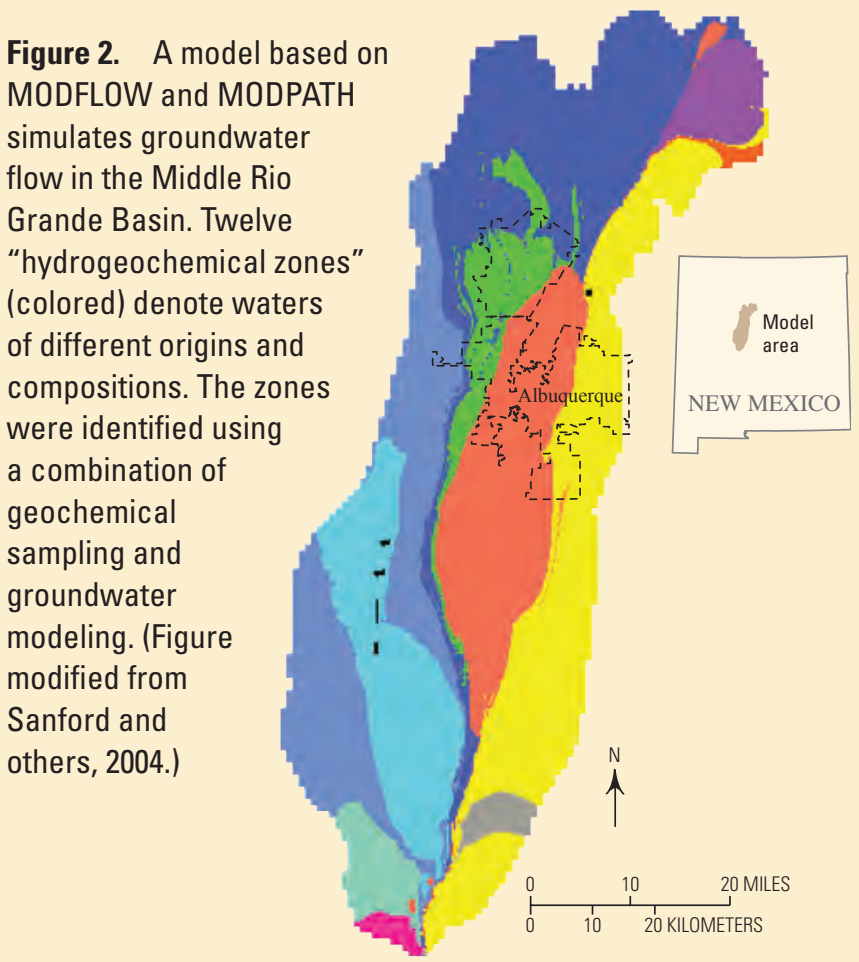

$\begin{array}{lll}\text { PHREEOE geochemical } & \begin{array}{l}\text { First version } \\ \text { onalysis software }\end{array} & \begin{array}{l}\text { SUTRA and HST3D variable-density } \\ \text { flow and transport modeling software }\end{array}\end{array}$


Table 1. Applications of USGS groundwater modeling software range from support of management decisions to cutting-edge research.

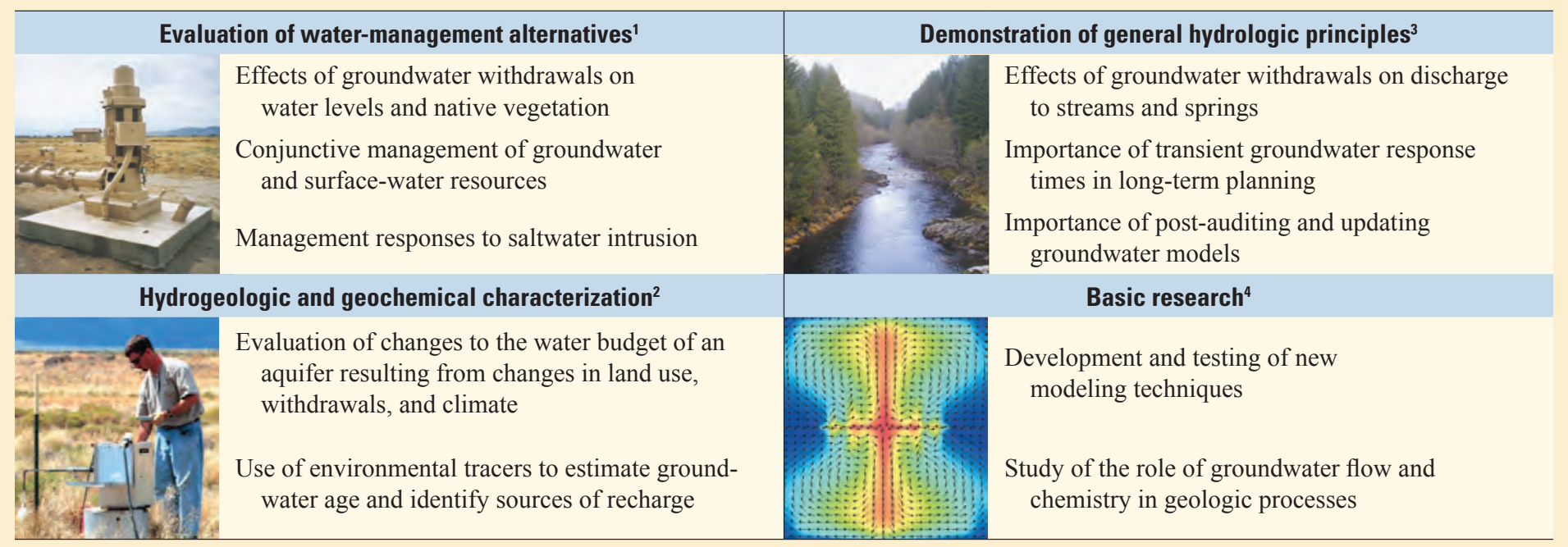

For more information, please see ${ }^{1}$ Galloway and others (2003), ${ }^{2}$ Reilly and others (2008), ${ }^{3}$ Alley and others (1999), and ${ }^{4}$ U.S. Geological Survey (2005). Photo and image credits, clockwise from upper left: Loren Metzger, USGS; Mark Uhrich, USGS; Christian Langevin, USGS; USGS Office of Human Resources.

\section{Today's Modeling Software}

In formulating a groundwater model of a specific hydrologic system, the hydrologist must choose which features and processes to include and the spatial and temporal scales at which to represent them based on the purpose of the study. A model that omits important characteristics of the groundwater system will not accurately simulate the behavior of interest, whereas one that includes unnecessary detail will be unwieldy and inefficient.

The variety of software developed by the USGS reflects the broad spectrum of applications that groundwater models are called upon to address. Some programs are designed to be adaptable to a wide range of complex problems. MODFLOW, the USGS's flagship groundwater-flow simulator, includes more than 20 "packages" and "processes" that have been added by individuals and groups both inside and outside of the USGS

All USGS groundwater modeling software is fully documented and available free-of-charge at http://water.usgs.gov/software/lists/groundwater/.

to take into account hydrologic processes such as land subsidence caused by groundwater withdrawals, interaction of aquifers with streams and lakes, and agricultural water use. General-purpose programs that simulate both flow and transport include SEAWAT, SUTRA, and HST3D, which account for the effects of variable density; PHAST, which includes multicomponent geochemical reactions; BIOMOC, which computes biodegradation of contaminants; HYDROTHERM, which simulates heat transport and flow of both liquid water and water vapor; VS2DT, which allows detailed representation of the unsaturated zone; and MODFLOW-GWT, which adds solutetransport capabilities to MODFLOW. The program MODPATH complements MODFLOW by computing particle tracks from simulated flow fields. Other programs, such as PHREEQC, are designed to efficiently carry out calculations in more restricted geometries or under specific hydrologic conditions.

\section{Relevant, Dependable, and Freely Available}

The distributed, application-driven approach to USGS groundwater modeling software development encourages innovation and results in programs that are versatile and relevant to today's water-resources problems. Every program is fully documented and peer reviewed to ensure quality before it is released to the public. Upon release, the program and its documentation and source code are available free-of-charge at http://water.usgs.gov/software/lists/groundwater/.

\section{A Rich Variety of Applications}

Groundwater modeling software plays an integral role in the USGS's research projects and cooperative waterresources studies with various Federal, State, and local agencies. Applications range from the highly practical to the theoretical (table 1). The resulting models not only provide tools for addressing specific water-management problems, but also shed light on broader issues related to the availability and sustainability of the Nation's groundwater resources. These issues include quantity and quality of groundwater and surface water, environmental preservation, land use, and water rights (Alley and others, 1999; Reilly and others, 2008).

Among the many scientific investigations that have relied on USGS modeling capabilities, one of the largest and most fruitful was the Regional Aquifer-System Analysis (RASA) Program. Between 1978 and 1995, USGS investigators created groundwater-flow and geochemical models to define the regional hydrogeology and establish a framework of geologic, hydrologic, and geochemical information for 25 of the Nation's major aquifer systems (Sun and Johnston, 1994). These models 
compose a solid platform for the critical and never-ending task of assessing changes in water availability and are updated as modeling techniques improve and environmental conditions and societal needs evolve (Reilly and others, 2008). Regional-scale RASA models also serve as the basis for more refined models designed to address groundwater-resources issues in smaller geographic areas.

\section{The Drive to Innovate}

The way in which USGS water-resources studies inspire and drive new development is exemplified by the advances in modeling made in RASA-related projects, in which regional scales and broad scientific scope posed a variety of new technical challenges. Investigators responded with a series of improvements and innovations that included a multiaquifer well-simulation technique, an improved method of simulating movement of variable-density groundwater, mass-transfer and reaction models, and basin geochemical models (Sun and Johnston, 1994). These efforts also spawned precursors to the widely used "Streamflow-Routing" and "Subsidence and Aquifer-System Compaction" packages for MODFLOW.

As the demand for our Nation's limited water resources continues to increase, the expectations placed on groundwater models show no sign of abating. In response, the USGS is continually developing software that enhances the power and utility of groundwater models. Supporting software includes graphical user interfaces, more efficient equation solvers, and parameter-estimation software that assists in model formulation and quantifies the uncertainties inherent in modeling real-life groundwater systems. Such advances and innovations help hydrologists apply their full understanding to today's complex water-resources problems.

\section{Solving Tomorrow's Challenges}

Scientists' increasing understanding and society's growing awareness of the interrelatedness of our natural resources requires ever-closer integration of the USGS's multidisciplinary approach to fulfilling its scientific mission (U.S. Geological Survey, 2008). The need to view water resources in a broader context, together with continual advances in computing power, is leading to the development of groundwater modeling software that increasingly brings together various fields of earth science and applied mathematics. Examples include PHAST, which combines three-dimensional groundwater flow with transport of reactive contaminants; GSFLOW, which simulates coupled groundwater and surface-water flow; the MODFLOW GWM process, which solves simulation-optimization problems; and the MODFLOW HUF package, which facilitates the integration of geologic information into groundwater models by allowing hydrologic properties to be input in terms of hydrogeologic units rather than model layers. As hydrologists design tomorrow's groundwater models to account for interactions between hydrologic, chemical, biological, geological, climatic, and human influences on ecosystems, USGS software will continue to provide the tools they need.

\section{References}

Alley, W.M., Reilly, T.E., and Franke, O.L., 1999, Sustainability of ground-water resources: U.S. Geological Survey Circular 1186, 79 p.; accessible online in November 2009 at http://pubs.usgs.gov/circ/circ1186/.

Back, William, and Cherry, J.A., 1976, Chemical aspects of present and future hydrogeologic problems, in Saleem, Z.A., ed., Advances in groundwater hydrology, Symposium proceedings: Chicago, American Water Resources Association., p. 153-172.

Bredehoeft, J.D., 1976, Status of quantitative groundwater hydrology, in Saleem, Z.A., ed., Advances in groundwater hydrology, Symposium proceedings: Chicago, American Water Resources Association, p. 8-14.

Bredehoeft, J.D., and Pinder, G.F., 1973, Mass transport in flowing groundwater: Water Resources Research, v. 9, no. 1, p. 194-210.

Galloway, D.L., Alley, W.M., Barlow, P.M., Reilly, T.E., and Tucci, P., 2003, Evolving issues and practices in managing ground-water resources-Case studies on the role of science: U.S. Geological Survey Circular 1247, 83 p.; accessible online in November 2009 at http://pubs.usgs.gov/circ/2003/circ1247/

Hem, J.D., 1985, Study and interpretation of the chemical characteristics of natural water (3d ed.): U.S. Geological Survey Water-Supply Paper 2254, 264 p.

Konikow, L.F., and Bredehoeft, J.D., 1978, Computer model of two-dimensional solute transport and dispersion in ground water: Techniques of Water-Resources Investigations of the U.S. Geological Survey, book 7, chap. C2, 90 p.

Langevin, C.D., 2001, Simulation of ground-water discharge to Biscayne Bay, southeastern Florida: U.S. Geological Survey Water-Resources Investigations Report 00-4251, 127 p.; accessible online in November 2009 at http://pubs. er.usgs.gov/usgspubs/wri/wri004251.

McDonald, M.G., and Harbaugh, A.W., 1984, A modular three-dimensional finite-difference ground-water flow model: U.S. Geological Survey Open-File Report 83-875, $528 \mathrm{p}$.

Parkhurst, D.L., Thorstenson, D.C., and Plummer, L.N., 1980, PHREEQE-A computer program for geochemical calculations: U.S. Geological Survey WaterResources Investigations Report 80-96, 195 p. (revised and reprinted August 1990).

Pinder, G.F., 1969, An iterative digital model for aquifer evaluation: U.S. Geological Survey Open-File Report 69-207, 35 p.

Plummer, L.N., Prestemon, E.C., and Parkhurst, D.L., 1991, An interactive code (NETPATH) for modeling NET geochemical reactions along a flow PATH: U.S. Geological Survey Water-Resources Investigations Report 91-4078, 227 p.

Prickett, T.A., 1976, Advances in groundwater modeling, in Saleem, Z.A., ed., Advances in groundwater hydrology, Symposium proceedings: Chicago, American Water Resources Association, p. 102-112.

Reilly, T.E., Dennehy, K.F., Alley, W.M., and Cunningham, W.L., 2008, Groundwater availability in the United States: U.S. Geological Survey Circular 1323 , 70 p.; accessible online in November 2009 at http://pubs.usgs.gov/circ/1323/.

Rubin, J., and James, R.V., 1973, Dispersion-affected transport of reacting solutes in saturated porous media-Galerkin method applied to equilibrium controlled exchange in unidirectional steady water flow: Water Resources Research, v. 9, no. 5, p. 1332-1356.

Sanford, W.E., Plummer, L.N., McAda, D.P., Bexfield, L.M., and Anderholm, S.K., 2004, Use of environmental tracers to estimate parameters for a predevelopment ground-water-flow model of the Middle Rio Grande Basin, New Mexico: U.S. Geological Survey Water-Resources Investigations Report 03-4286, 102 p.

Sun, R.J., and Johnston, R.H., 1994, Regional Aquifer-System Analysis Program of the U.S. Geological Survey, 1978-1992: U.S. Geological Survey Circular 1099 $126 \mathrm{p}$.

Theis, C.V., 1935, The relation between the lowering of the piezometric surface and the rate and duration of discharge of a well using groundwater storage: Transactions of the American Geophysical Union, v. 16, p. 519-524.

Trescott, P.C., 1975, Documentation of finite-difference model for simulation of three-dimensional ground-water flow: U.S. Geological Survey Open-File Report 75-438, 32 p.

Truesdell, A.H., and Jones, B.F., 1974, WATEQ, a computer program for calculating chemical equilibrium of natural waters: Journal of Research of the U.S. Geological Survey, v. 2, no. 2, p. 233-248.

U.S. Geological Survey, 2005, The National Research Program in the hydrological sciences: U.S. Geological Survey Fact Sheet 2005-3015, 2 p.; accessible online in November 2009 at http://pubs.usgs.gov/fs/2005/3015/.

U.S. Geological Survey, 2008, Facing tomorrow's challenges-An overview: U.S. Geological Survey Fact Sheet 2008-3008, 4 p.; accessible online in November 2009 at http://pubs.usgs.gov/fs/2008/3008/.

By Alden M. Provost, Thomas E. Reilly, Arlen W. Harbaugh, and David W. Pollock 